\title{
Taura syndrome virus (TSV) in Thailand and its relationship to TSV in China and the Americas
}

\author{
Linda Nielsen ${ }^{1}$, Wiwat Sang-oum ${ }^{1}$, Supapon Cheevadhanarak ${ }^{2}$, Timothy W. Flegel ${ }^{1, *}$ \\ ${ }^{1}$ Centex Shrimp, Faculty of Science, Mahidol University, Rama 6 Road, Bangkok 10400, Thailand and National Center \\ for Genetic Engineering and Biotechnology, 113 Paholyothin Rd., Klong 1, Klong Luang, Phtthumthani 12120, Thailand \\ ${ }^{2}$ School of Bioresources and Technology, King Mongkut's University of Technology, Thonburi, Bangkuntien, \\ Bangkok 10150, Thailand
}

\begin{abstract}
The cultivation of exotic Penaeus vannamei in Thailand began on a very limited scale in the late 1990s, but a Thai government ban on the cultivation of $P$. monodon in freshwater areas in 2000 led many Thai shrimp farmers to shift to cultivation of $P$. vannamei. Alarmed by the possibility of Taura syndrome virus (TSV) introduction, the Thai Department of Fisheries required that imported stocks of $P$. vannamei be certified free of TSV by RT-PCR (Reverse Trasciption Polymerase Chain Reaction) testing. During the interval of allowed importation, over 150000 broodstock shrimp were imported, $67 \%$ of these from China and Taiwan. Despite the safeguards, TSV outbreaks occurred and we confirmed the first outbreak by RT-PCR in early 2003. This resulted in a governmental ban on all shrimp broodstock imports from February 2003, but TSV outbreaks have continued, possibly due to original introductions or to the continued illegal importation of stocks. To determine the origin of the TSV in Thailand, the viral coat protein gene VP1 was amplified by RT-PCR from several shrimp specimens found positive for TSV by RT-PCR from January to November 2003. These included 7 samples from $P$. vannamei disease outbreaks in Thailand, 3 other non-diseased shrimp samples from Thailand and Burma and 6 samples including P. vannamei and P. japonicus from China. Comparison revealed that the Thai, Burmese and Chinese TSV types formed a clade distinct from a clade of TSV types from the Americas.
\end{abstract}

KEY WORDS: Taura syndrome virus $\cdot$ TSV $\cdot$ Thailand $\cdot$ Phylogeny $\cdot$ VP1

\section{INTRODUCTION}

Taura syndrome (TS) was first described as a shrimp disease in Ecuador in 1992 (Jimenez 1992). Both toxic and infectious aetiologies were considered. An infectious agent was subsequently described in 1995 and named Taura syndrome virus or TSV (Hasson et al. 1995, Lightner et al. 1995). However, the authors of the original Taura syndrome report disputed that TSV was the cause of TS and recommended that TSV be instead called infectious cuticular epithelial necrosis virus (ICENV) (Intriago et al. 1997). The history of the dispute has been reviewed (Brock et al. 1995, Brock et al. 1997). Here, the virus will be referred to as TSV.

TSV is a cytoplasmic, non-enveloped icosahedral virus of $32 \mathrm{~nm}$ diameter. It has a buoyant density of
$1.338 \mathrm{~g} \mathrm{ml}^{-1}$ and its genome consists of a linear, positive-sense ssRNA of approximately $10.2 \mathrm{~kb}$. It was first tentatively classified as a picornavirus (Bonami et al. 1997, Brock et al. 1997) but later included in the genus Cripavirus, family Dicistroviridae (RoblesSikisaka et al. 2001, Mari et al. 2002, Mayo 2002). It was a serious cause of shrimp mortality for reared Penaeus vannamei in the Americas where it spread principally through the regional and international transfer of live postlarvae and broodstock (Brock et al. 1997). More recently, it was reported from P. vannamei reared in Taiwan after importation of live shrimp stocks from the Americas (Tu et al. 1999). Although TSV infects a number of penaeid species (Lightner 1996), it has caused serious commercial losses only for juvenile to adult stages of $P$. vannamei. 
The following information is summarized from a Thai Government publication on the impact of Penaeus vannamei importation in Thailand (Anonymous 2004). The cultivation of exotic $P$. vannamei in Thailand began on a very limited scale in the late 1990s. However, a Thai government ban on the cultivation of $P$. monodon in freshwater areas in 2000 led many shrimp farmers there to shift to cultivation of $P$. vannamei, and the importation of stocks increased sharply with the subsequent rise in demand and price of post larvae (PL). Imported specific pathogen free (SPF) stocks originating from breeding programs such as that at the Oceanic Institute, Hawaii, grew well, especially in the cool rainy season when $P$. monodon traditionally performed less well. High growth rates for the selected stocks allowed harvests of marketable shrimp at 15 to $20 \mathrm{t} \mathrm{ha}^{-1}$ within 3 to 4 mo. Dissatisfaction with widespread slow growth in cultivated P. monodon in 2001 and 2002 (Chayaburakul et al. 2004) led to even wider adoption of $P$. vannamei as an alternative. Although importation and rearing of these stocks was illegal, government regulations could not be enforced and the demand and price of PL rose further, stimulating more illegal importation. Alarmed by the possibility of TSV introduction, the Department of Fisheries permitted legal importation of $P$. vannamei in mid 2002, if the imported stocks were certified free of TSV by RT-PCR testing. During the interval, over 150000 broodstock shrimp were officially imported, $67 \%$ of these from China and Taiwan. In spite of these safeguards, we confirmed the first TSV outbreak by RT-PCR in early 2003 (reported in this study) and reported it to the Thai Department of Fisheries. This resulted in a governmental ban on all shrimp broodstock imports from February 2003. Despite this ban, TSV outbreaks continued.

In this report, we summarize an analysis of the viral coat protein gene amplified by RT-PCR from several isolates of TSV associated with shrimp Penaeus vannamei disease outbreaks in Thailand, from a few non-diseased shrimp from Thailand and Burma and from several shrimp samples from China. We discuss the implications for importation of exotic stocks.

\section{MATERIALS AND METHODS}

Thai shrimp were delivered live to our laboratory over the period of January to July 2003 for RNA extraction and RTPCR analysis according to the protocol described in the IQ2000 test kit for Taura syndrome virus (TSV) (Farming Intelligene Technology). Seven positive isolates (Th-1 to Th-7) were obtained from Thai farms experiencing Penaeus vannamei disease outbreaks with gross signs of the acute and/or recovery phases of TSV infection (Lightner 1996, Hasson et al. 1999) in the provinces of Chatcheonchao (1), Ratchaburi (1), Chantaburi (1), Chonburi (1) and Nakornphatom (3). In addition, there were 2 non-diseased specimens, one of $P$. monodon (Th-8) and one of Macrobrachium rosenbergii (Th-6) that also tested TSV positive with the IQ2000 kit. From outside of Thailand, we obtained 1 frozen sample of $P$. monodon from Burma (Th-10, in July 2003) and 6 total RNA extracts of samples of $P$. vannamei (Ch-1 to Ch-4 and Ch-6) and $P$. japonicus (Ch-5) from China (in November 2003) that tested positive for TSV by RT-PCR with the same test kit (Farming Intelligene Technology). The Thai $P$. monodon sample was obtained from a pond where it had been stocked subsequent to a TSV outbreak in previouslyreared $P$. vannamei and during the interval when dead and living $P$. vannamei were still present. The Burmese sample comprised frozen shrimp transported to Thailand for processing. The source and codes for all these isolates are listed in Table 1.

The samples were used for RT-PCR according to the protocol of Erickson et al. (2002) to obtain 1303 bp amplicons of the VP1 portion of the viral coat protein gene of TSV. The PCR product was confirmed by gel electrophoresis, cloned using a TOPO TA Cloning kit for sequencing (Invitrogen) and sequenced from both strands by Macrogen.

Amplicon sequences were converted to deduced amino acid sequences and aligned with American

Table 1. Sources and codes of samples (Penaeus vannamei, P. monodon, P. japonicus, Macrobrachium rosenbergii) used for analysis and GenBank accession numbers for the VP1 portion of the TSV viral coat protein gene. Th: Thailand; Ch: China

\begin{tabular}{|llcccc|}
\hline Code & $\begin{array}{c}\text { Source } \\
\text { species }\end{array}$ & $\begin{array}{c}\text { Source } \\
\text { country }\end{array}$ & Province & $\begin{array}{c}\text { Date } \\
\text { (dd/mm/yy) }\end{array}$ & GenBank \# \\
\hline Th-1 & P. vannamei & Thailand & Chatcheonchao & $28 / 01 / 03$ & AY755587 \\
Th-2 & P. vannamei & Thailand & Ratchaburi & $02 / 05 / 03$ & AY755588 \\
Th-3 & P. vannamei & Thailand & Chantaburi & $29 / 05 / 03$ & AY755589 \\
Th-4 & P. vannamei & Thailand & Chonburi & $29 / 01 / 03$ & AY755590 \\
Th-5 & P. vannamei & Thailand & Nakornphatom & $21 / 05 / 03$ & AY755591 \\
Th-6 & M. rosenbergii & Thailand & Nakornphatom & $04 / 07 / 03$ & AY755592 \\
Th-7 & P. vannamei & Thailand & Nakornphatom & $23 / 07 / 03$ & AY755593 \\
Th-8 & P. monodon & Thailand & Nakornphatom & $31 / 07 / 03$ & AY755594 \\
Th-9 & $P$. vannamei & Thailand & Nakornphatom & $31 / 07 / 03$ & AY755595 \\
Th-10 & P. monodon & Burma & Unknown & $31 / 07 / 03$ & AY755596 \\
Ch-1 & P. vannamei & China & Unknown & $-/ 11 / 03$ & AY755597 \\
Ch-2 & P. vannamei & China & Unknown & $-/ 11 / 03$ & AY755598 \\
Ch-3 & P. vannamei & China & Unknown & $-/ 11 / 03$ & AY755599 \\
Ch-4 & P. vannamei & China & Unknown & $-/ 11 / 03$ & AY755600 \\
Ch-5 & P. japonicus & China & Unknown & $-/ 11 / 03$ & AY755601 \\
Ch-6 & P. vannamei & China & Unknown & $-/ 11 / 03$ & AY755602 \\
\hline
\end{tabular}


TSV sequences recorded at GenBank (Hawaiian HI94TSV GenBank AF510518, Ecuadorian EC93TSV GenBank AF277675 and Mexican SIN98TSV GenBank AF510515, MX99TSV GenBank AF510516 and SON2KTSV GenBank AF510517 using Clustal W (1.82) (Thompson et al. 1994). Data for phylogenetic trees was generated by PRODIST/NEIGHBOR of Phylip (Version 3.57 c, Felsenstein 1993) based on aa similarities using 1000 bootstrap replicates, while trees were drawn using TREECON for Windows [Version 1.3b, Yves Van de Peer, Department of Biochemistry, University of Antwerp, Belgium].

\section{RESULTS}

Rumors of disease outbreaks with gross signs of acute and/or recovery phases of TSV in Thai farms rearing Penaeus vannamei began in late 2002 but we received the first samples showing reddened tails (acute phase) and black cuticular lesions (recovery phase) in January 2003 and subjected all such samples to RT-PCR analysis for TSV. We did not conduct a prevalence survey but simply analyzed samples submitted to the laboratory. The samples that gave positive RT-PCR test results are listed in Table 1 together with the dates of collection.

The deduced VP1 protein sequences derived from the samples analyzed were deposited at GenBank under the accession numbers listed in Table 1 . When compared for amino acid (aa) identity, the deduced VP1 protein sequences of the 10 Thai samples grouped into 4 TSV types that shared $99.6 \%$ mean aa identity to Thai sample 5 while the 6 Chinese samples gave 4 TSV types that shared $99.7 \%$ mean identity to Chinese sample 2 (Table 2).

When compared for identity to the originally described TSV sequence from Hawaii (HI94TSV GenBank AF510518) the Thai and Chinese isolates showed

Table 2. Percent amino acid identity for the deduced VP1 protein sequences of 10 Thai samples compared to Th-5, and 6 Chinese samples compared to Ch-2

\begin{tabular}{|lrcc|}
\hline $\begin{array}{l}\text { Thai isolates } \\
\text { vs Th-5 }\end{array}$ & \% identity & $\begin{array}{c}\text { Chinese isolates } \\
\text { vs Ch-2 }\end{array}$ & \% identity \\
\hline Th-1, 4 & 98.2 & Ch-1 & 99.7 \\
Th-2, 3 & 99.7 & Ch-2, 3,5 & 100 \\
Th-5, 6, 8, 9, 10 & 100.0 & Ch-4 & 99.5 \\
Th-7 & 99.7 & Ch-6 & 99.1 \\
Mean identities & 99.6 & & 99.7 \\
\hline
\end{tabular}

lower levels of mean identity (97.6 and 97.8\%, respectively) than did the American isolates of TSV amongst themselves (98.6\%) (Table 3).

A detailed aa sequence alignment for VP1 from the various TSV types is shown in Fig. 1. In addition, the phylogenetic tree shown in Fig. 2 clearly shows that the Thai sequences cluster together with the Chinese sequences as a clade distinct from the American sequences. Essentially the same tree was obtained with the DNA sequences (not shown). In addition, most of the Thai samples (8/10) fall within a sub-clade distinct from the Chinese samples. The Thai sub-clade includes TSV from 1 Macrobrachium rosenbergii sample (Th-6) and 2 Penaeus monodon samples (1 from Thailand [Th-8] and 1 from Burma [Th-10]).

\section{DISCUSSION}

Taura syndrome was first described in Penaeus vannamei in the Americas in 1992 (Jimenez 1992) and then from $P$. vannamei in Taiwan (China) in 1999 (Tu et al. 1999) followed by Thailand in January 2003 (this report). In Taiwan, it was suggested that TSV was introduced via contaminated $P$. vannamei imported from Ecuador (Tu et al. 1999) and a subsequent genetic comparison of Taiwanese and American TSV isolates from 2000 (Robles-Sikisaka et al. 2002) supported this contention. Since the deduced VP1 protein sequences of the Thai and Chinese isolates grouped together as a clade distinct from the American isolates it is possible either that the Thai types resulted from importation of living $P$. vannamei stocks from China or that the Thai and Chinese stocks originated from multiple imports of live stocks from the same source in the Americas. Given the chronology of the Chinese and Thai TSV outbreaks and the fact that the majority of the stocks imported to Thailand came from China (Anonymous 2004), it is likely that at least some of the Thai types originated from Chinese stocks.

It is important to consider that our Chinese samples were collected in November 2003, 5 yr after the first outbreaks occurred in Taiwan (i.e. reported in 1999, but started in 1998) (Tu et al. 1999) and 3 years after the 


Ch-6
Ch-4
Ch-2, 3, 5
Ch-1
Th-7
Th-5, 6, 8, 9, 10
Th-2, 3
Th-1, 4
HI 94 /EC93
SIN 98
MX99
SON2K

Ch-6
Ch-4
Ch-2, 3, 5
Ch-1
Th-7
Th-5, 6, 8, 9, 10
Th-2, 3
Th-1, 4
HI94/EC93
SIN 98
MX99
SON2K

Ch- 6

$\mathrm{Ch}-4$

Ch $-2,3,5$

Ch-1

Th-7

Th-5, 6, 8, 9, 10

Th-2, 3

Th-1, 4

HI 94 /EC93

SIN98

MX99

SON2K

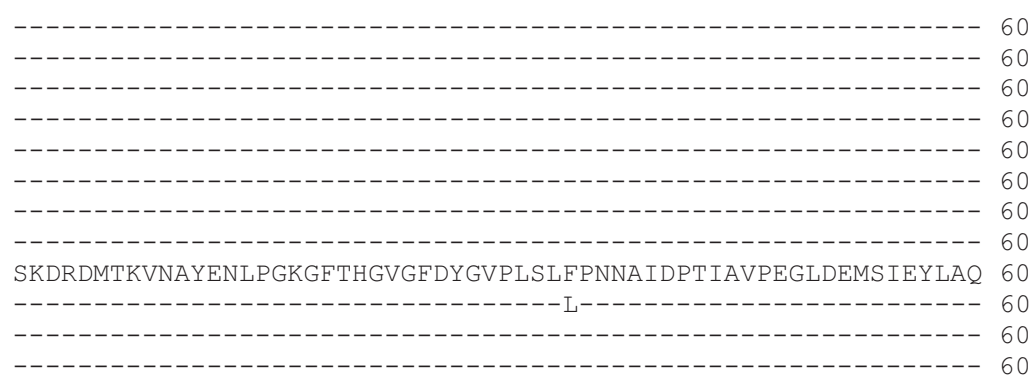

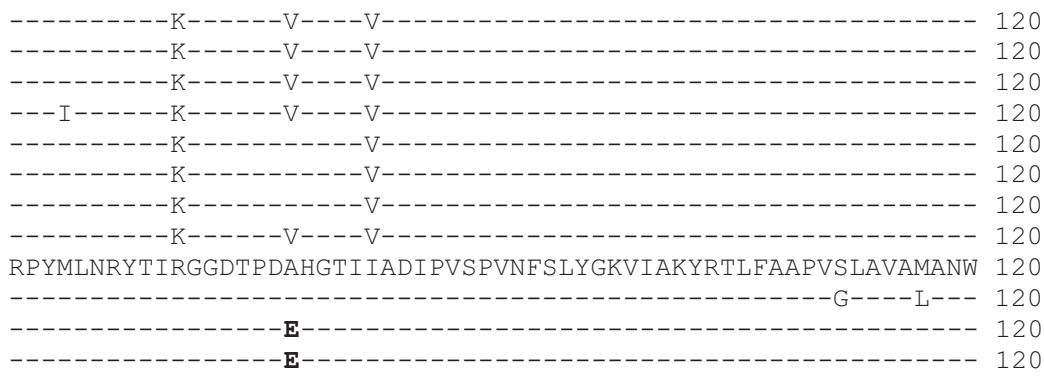

$------------------------------------------------------------180$

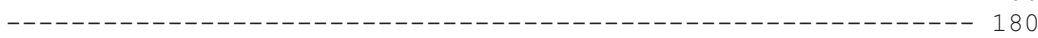

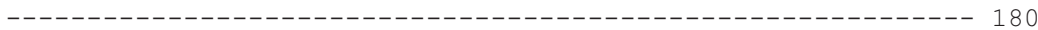

$---------------------------------------------------------180$

- - - - - - - - - - - - - - - - - - - - - - - - - - - - - - - - - - - - - - - - - - - - 180

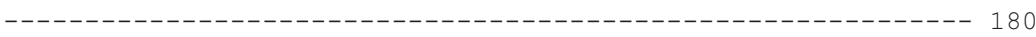

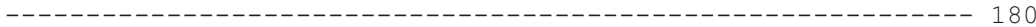

$--------------------------------------------------------180$

WRGNINLNLRFAKTQYHQCRLLVQYLPYGSGVQPIESILSQIIDISQVDDKGIDIAFPSV 180

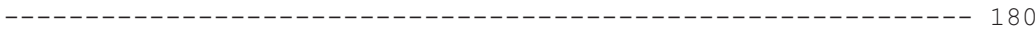

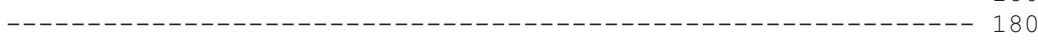

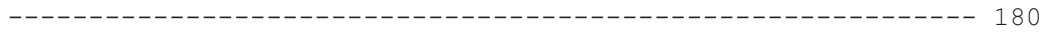

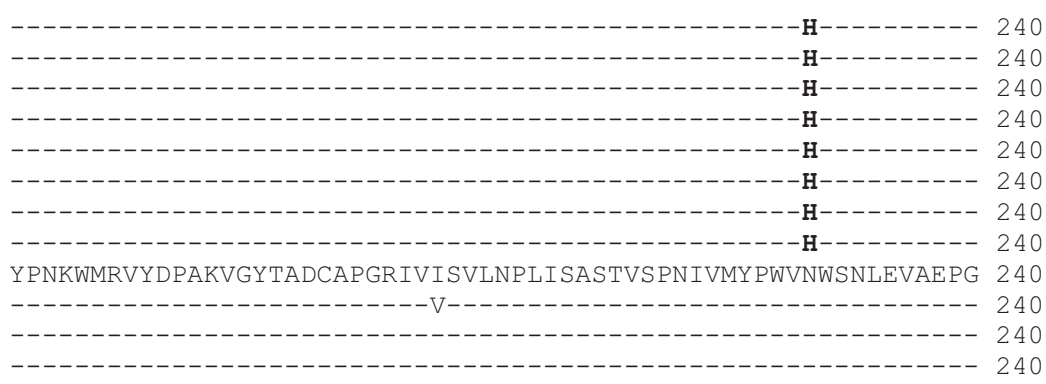

Ch-6
Ch-4
Ch-2, 3, 5
Ch-1
Th-7
Th-5, 6, 8, 9, 10
Th-2, 3
Th-1, 4
HI94/EC93
SIN98
MX99
SON2K

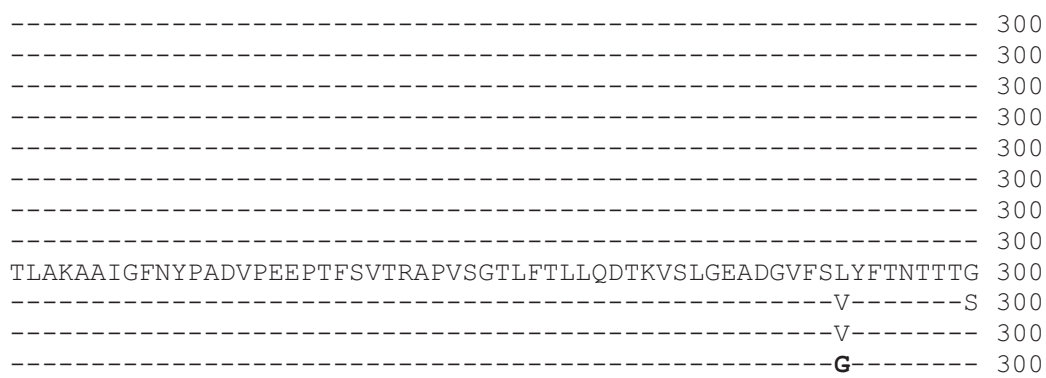

Fig. 1. Comparison of deduced amino acid (aa) sequences of VP1 protein from various TSV isolates. Non-conservative differences in aa relative to the HI94/EC93 sequence are marked in bold print. Ch: China; Th: Thailand. All other aa sequences are from 


Ch-6
Ch-4
Ch-2, 3, 5
Ch-1
Th-7
Th-5, 6, 8, 9, 10
Th-2, 3
Th-1, 4
HI94/EC93
SIN98
MX99
SON2K

$\mathrm{Ch}-6$
$\mathrm{Ch}-4$
$\mathrm{Ch}-2,3,5$
$\mathrm{Ch}-1$
$\mathrm{Th}-7$
$\mathrm{Th}-5,6,8,9,10$
$\mathrm{Th}-2,3$
$\mathrm{Th}-1,4$
HI94/EC93
SIN98
MX99
SON2K
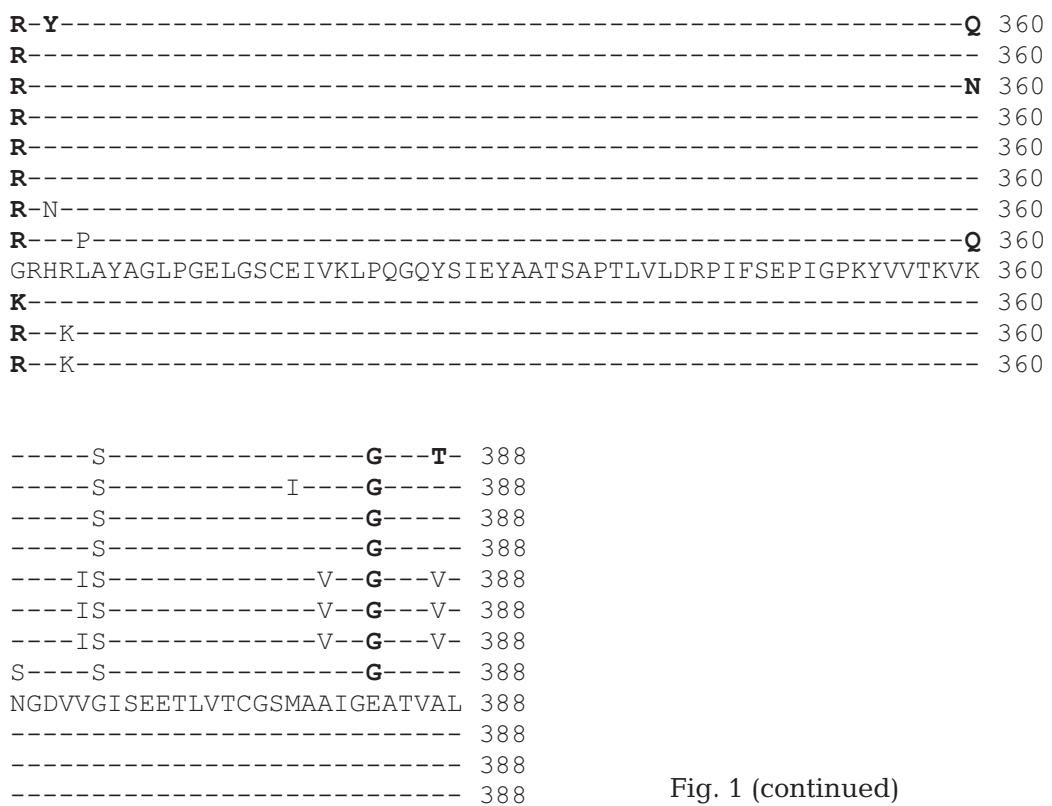

Fig. 1 (continued) samples used in an earlier study that examined genetic variation in TSV geographical isolates (Robles-Sikisaka et al. 2002). During the interval 1998 to 2003, we have anecdotal information that most of the Penaeus vannamei PL used by Chinese shrimp farmers were derived from shrimp stocks locally reproduced for several generations from a relatively small number of original American imports. If so, one would expect to eventually see a phylogenetic tree with Chinese TSV variants that evolved locally from a narrow genetic base - one possi-

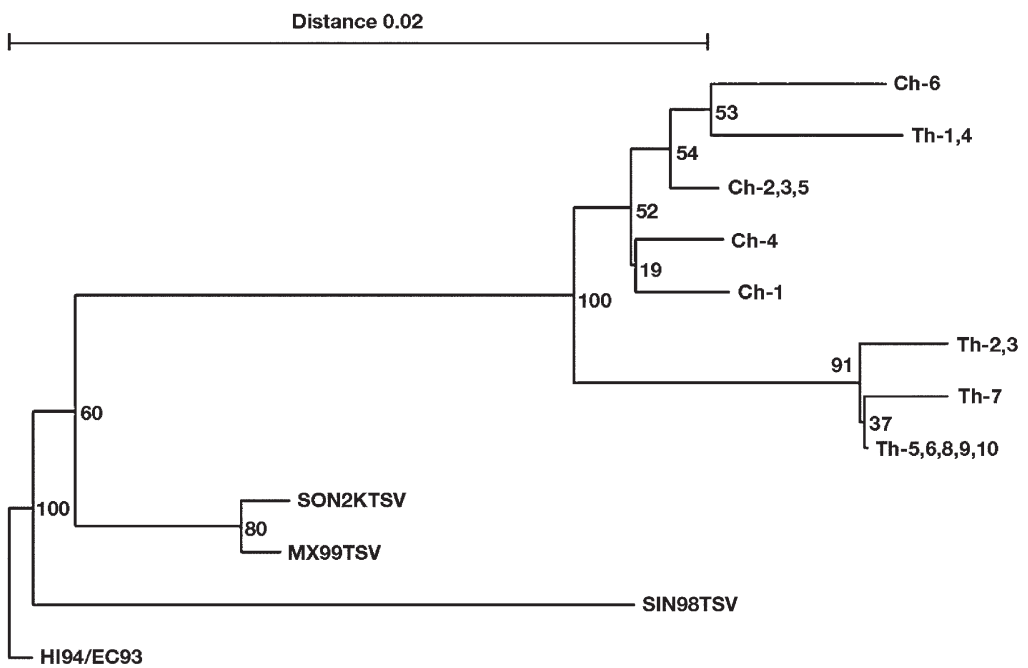

Fig. 2. Phylogenetic tree of deduced VP1 protein sequences from American, Chinese (Ch) and Thai (Th) isolates. It can be seen that the Thai and Chinese isolates fall into a single clade and the American isolates into another clade. Most of the Thai isolates (8/10) fall into a distinct sub-clade of the ThaiChinese clade. The bootstrap values at the branch points represent percentage of 1000 replicates ble interpretation of our phylogenetic tree. Comparison of our Thai and Chinese TSV aa sequences with 2 Taiwanese sequences derived from year 2000 samples (Robles-Sikisaka et al. 2002) was possible for only a small portion of VP1. However, it revealed that all the sequences shared a non-conservative aa difference of histidine $(\mathrm{H}$, positively charged) versus asparagine $(\mathrm{N}$, polar, uncharged) at position 230 of the Hawaiian/ Ecuador sequence. By contrast, our Thai and Chinese sequences were identical to the Hawaiian/Ecuador sequence at position 235 where the 2 previous Taiwanese samples showed a nonconservative difference of alanine (A, nonpolar) versus glutamic acid (E, negatively charged) (Robles-Sikisaka et al. 2002). Finally, the previous Taiwanese and all our Chinese and Thai types shared a common serine (S) at position 112 of the Hawaiian/ Ecuador sequence. This corresponded to sequences from 1 clade including Ecuadorian isolates but not another clade with only Mexican isolates in the earlier study (RoblesSikisaka et al. 2002). Altogether, the chronology of outbreaks, the sequence information and phylogenetic trees from both studies are consistent with the proposal that TSV was introduced first to Taiwan by imports of contaminated shrimp from Ecuador. The later Thai outbreaks probably occurred by the introduction of contaminated stocks directly from the Americas (e.g. the Thai subclade) and indirectly from the Americas via China (e.g. Th-1, Th-4) (Fig. 2). 
It was curious that 3 of the 4 Thai TSV types grouped into an all-Thai sub-clade while 1 type was included in a sub-clade dominated by Chinese types. It is possible that the Thai sub-clade arose because several Thai PL producers (like their Chinese counterparts) engage in the practice of onward reproduction of imported stocks (Anonymous 2004). Thus, a limited importation of contaminated stocks would be expected to lead to TSV evolution from a narrow genetic base.

There is little information about the effect of TSV on Penaeus monodon and other native penaeid shrimp in Asia. An early report suggested that $P$. monodon was relatively unaffected by TSV (Brock et al. 1997) and indeed, the Thai $P$. monodon sampled in this study were grossly normal and showed no signs of TSV infection. However, TSV mutates rapidly and it is known that the American genetic variants differ in pathogenicity for P. vannamei (Erickson et al. 2002). Thus, it is possible that some of the new genetic variants in Thailand could eventually become problematic for $P$. monodon, even if they are not so at this time. The potential impact of TSV on other Thai native shrimp species or other crustaceans is also unknown.

TSV introduction to Thailand with broodstock and fry for aquaculture adds to previous examples (Flegel \& Fegan 2002), indicating that careless international movement of stocks should be discouraged. The practice is particularly dangerous for crustaceans because of their propensity to carry multiple viral pathogens without gross signs of disease (Flegel 2001, Flegel et al. 2004).

Acknowledgements. This work was partially supported by research grants from the National Center for Genetic Engineering and Biotechnology and from the Mahidol University Grant for Research 2002-2003.

\section{LITERATURE CITED}

Anonymous (2004) The impact of introduction of white shrimp (Penaeus vannamei) into Thailand. Dept Fisheries, Government of Thailand, Bangkok

Bonami JR, Hasson KW, Mari J, Poulos BT, Lightner DV (1997) Taura syndrome of marine penaeid shrimp: characterization of the viral agent. J Gen Virol 78:313-319

Brock JA, Gose R, Lightner DV, Hasson KW (1995) An overview on Taura syndrome, an important disease of farmed Penaeus vannamei. In: Browdy CL, Hopkins JS (eds) Swimming through troubled water. Proceedings of the special session on shrimp farming. World Aquaculture Society, Baton Rouge, LA, p 84-94

Brock JA, Gose RB, Lightner DV, Hasson KW (1997) Recent developments and an overview of Taura syndrome of farmed shrimp in the Americas. In: Flegel TW, MacRae IH (eds) Diseases in Asian aquaculture. III. Fish health section. Asian Fisheries Society, Manila, p 267-283

Chayaburakul K, Nash G, Pratanpipat P, Sriurairatana S,
Withyachumnarnkul B (2004) Multiple pathogens found in growth-retarded black tiger shrimp Penaeus monodon cultivated in Thailand. Dis Aquat Org 60:89-96

Erickson HS, Zarain-Herzberg M, Lightner DV (2002) Detection of Taura syndrome virus (TSV) strain differences using selected diagnostic methods: diagnostic implications in penaeid shrimp. Dis Aquat Org 52:1-10

Felsenstein J (1993) PHYLIP: phylogeny inference package. University of Washington, Seattle, WA

Flegel TW (2001) The shrimp response to viral pathogens. In: Browdy CL, Jory DE (eds) The new wave. Proceedings of the special session on sustainable shrimp aquaculture. World Aquaculture 2001, Orlando, January 20-25. World Aquaculture Society, Boca Raton, FL, p 190-214

Flegel TW, Fegan DF (2002) Strategies for preventing the spread of fish and shellfish diseases. Fish Sci 68:776-788 Suppl 1

Flegel TW, Nielsen L, Thamavit V, Kongtim S, Pasharawipas $\mathrm{T}$ (2004) Presence of multiple viruses in non-diseased, cultivated shrimp at harvest. Aquaculture 240:55-68

Hasson KW, Lightner DV, Poulos BT, Redman RM, White BL, Brock JA, Bonami JR (1995) Taura Syndrome in Penaeus vannamei: Demonstration of a viral etiology. Dis Aquat Org 23:115-126

Hasson KW, Lightner DV, Mohney LL, Redman RM, Poulos BT, White BM (1999) Taura syndrome virus (TSV) lesion development and the disease cycle in the Pacific white shrimp Penaeus vannamei. Dis Aquat Org 36:81-93

Intriago P, Jimenez R, Machuca M, Barniol R, Krauss E, Salvador X (1997) Experiments on toxicosis as the cause of Taura syndrome in Penaeus vannamei (Crustacea: Decapoda) in Ecuador. In: Flegel TW, MacRae IH (eds) Diseases in Asian aquaculture. III. Fish health section. Asian Fisheries Society, Manila, p 365-379

Jimenez R (1992) Sindrome de Taura (Resumen). Acuacultura del Ecuador:1-16

Lightner DV (1996) A handbook of pathology and diagnostic procedures for diseases of penaeid shrimp. World Aquaculture Society, Baton Rouge, LA

Lightner DV, Redman RM, Hasson KW, Pantoja CR (1995) Taura syndrome in Penaeus vannamei (Crustacea: Decapoda): gross signs, histopathology and ultrastructure. Dis Aquat Org 21:53-59

Mari J, Poulos BT, Lightner DV, Bonami JR (2002) Shrimp Taura syndrome virus: genomic characterization and similarity with members of the genus Cricket paralysis-like viruses. J Gen Virol 83:915-926

Mayo MA (2002) ICTV at the Paris ICV: Results of the plenary session and the binomial ballot. Arch Virol 147:2254-2260

Robles-Sikisaka R, Garcia DK, Klimpel KR, Dhar AK (2001) Nucleotide sequence of 3 '-end of the genome of Taura syndrome virus of shrimp suggests that it is related to insect picornaviruses. Arch Virol 146:941-952

Robles-Sikisaka R, Hasson KW, Garcia DK, Brovont KE, Cleveland KD, Klimpel KR, Dhar AK (2002) Genetic variation and immunohistochemical differences among geographical isolates of Taura syndrome virus of penaeid shrimp. J Gen Virol 83:3123-3130

Thompson JD, Higgins DG, Gibson TJ (1994) ClustalW: improving the sensitivity of progressive multiple sequence alignment through sequence weighting, position specific gap penalties and weight matrix choice. Nucleic Acids Res 22:4673-4680

Tu C, Huang HT, Chuang SH, Hsu JP, and 5 others (1999) Taura syndrome in Pacific white shrimp Penaeus vannamei cultured in Taiwan. Dis Aquat Org 38:159-161 